\title{
Development and Evaluation of an Android-based Yoruba Language Proverbs Preservatory and Repository System
}

\author{
Oyelami M.O. \\ Bowen University, Iwo \\ Nigeria
}

\author{
R.F. Famutimi \\ Bowen University, Iwo \\ Nigeria
}

\author{
T.S. Fadare \\ Bowen University, Iwo \\ Nigeria
}

\begin{abstract}
Yoruba language in Nigeria is one of the several languages of the world that face extinction, and proverbs are an important component of languages, especially Yoruba language. A good mastery of Yoruba proverbs is an indication that the speaker has an in-depth knowledge of the language. However, the current generation of Yoruba youths do not understand the proverbs in the language let alone how to use them in their writings and speeches. Hence, there is a need to preserve the proverbs in the language for these young and future generations in a bid to ensure continuity and prevent the extinction that looms over these proverbs. Towards preserving these proverbs and ultimately preserving the language, an Android-based Yoruba language proverbs preservatory and repository system was developed and its success evaluated majorly among the age groups that need to learn them based on DeLone and Mclean Success Model. The results show that the system was successful. This means that systems of this nature can be used as a platform for the young and future generations to learn Yoruba proverbs and their usage towards ultimately preserving the language and removing the extinction that looms over it.
\end{abstract}

\section{General Terms}

Language Extinction, E-learning, Information Success Model, Android-Based

\section{Keywords}

Proverbs, Repository, User Satisfaction, Acceptability, Yoruba Language

\section{INTRODUCTION}

Language is a means of communication, and communication is an inevitable phenomenon in any society of living beings. During the celebration of the international year of languages by United Nations Educational, Scientific and Cultural Organization it was confirmed that in every two weeks, a language ceased to exist [1]. Many linguists have also opined that gradually, many languages in the world are going into extinction. This means that in a few generations to this time, more than half of the 7,000 languages spoken in the world will go into extinction. Also, about $96 \%$ of the languages of the world are spoken by only $4 \%$ of the population. It was maintained that a lot of the world's major languages face the risk of extinction due to poor understanding of the geographical patterns and drivers of extinction risk [2]. Official languages of communication, accepted languages for business transactions, social strata and the perceived economic gains in other languages different from mother tongues have been identified to also be responsible for the looming extinction over languages [3]. Gulati posited that it is a common notion among young generation that indigenous languages are outdated for the modern world [4]. Olajide, in his work, submitted that the compulsory use of the colonial masters' language as an official language in place of Yoruba in Yoruba land has contributed to the gradual extinction of the language [5]. All the aforementioned have necessitated the need for the preservation of the endangered languages .Consequently, UNESCO has advised all nations to work on the preservation of their indigenous languages to prevent them from extinction.

One of the ways by which a language can be prevented from extinction is to work on its documentation and make it easily available before the last speaker of such a language dies. Gulati also opined that sincere and serious efforts to bring the endangered languages into the digital world would help to address the dangerous trend of extinction and consequently proposed the development of applications (apps) that use audio, video and complex step-by-step procedures to provide an effective learning environment for endangered languages [4]. This, according to the author will allow for large-scale technological revitalization and at the same time solve the problem of endangered languages being tagged as antiquated.

As earlier identified, one of the languages that are fast becoming extinct is the Yoruba language. Yoruba is a language spoken by about thirty million people in Nigeria and the neighboring West African countries of Togo and Republic of Benin. A component of Yoruba language and indeed other languages that is used to drive home points in different situations like hunger, love, hatred, pleasure, etc is proverb [5]. Proverbs are convincing formulations of social advice that are brief and memorable in nature. They are also gathered from accumulated experiences [6]. Proverbs were described as the simple truths of life that contain the ethical and moral values of the society. Proverbs in Yoruba language can be used to advise and guide people on different issues. For example a proverb like "òkánjúwà baba àrùn" (covetousness is the greatest of illnesses), is used to advise people to beware of greed because it is worse than any type of sickness [7]. There is also a proverb in Yoruba that goes like this: "Eyin lòrò, bó bá balệ, fifọ̣ ní ńfọ́ (speech is an egg, if it drops on the floor, it is broken). This proverb shows how Yorubas are cautious of what they say because of its consequences.

Being able to support one's points with proverbs shows one's in-depth knowledge of the language and people in this category are generally believed to be wise and full of knowledge. In this work, in a bid to preserve these proverbs and ultimately preserving the language, is reported the development of an Android-based Yoruba language proverbs and repository system. The success of the developed system 
was evaluated using DeLone and Mclean Success Model predominantly among the youths in the age group 15-30 who need it most and the findings are presented [8].

\section{E-LEARNING}

In today's world, the advancement in technology coupled with the convenience of ubiquitous learning, cost effectiveness and being able to work any time has made the use of elearning an interesting option to adopt in learning activities. This has encouraged many higher institutions of learning to adopt the use of both traditional and e-learning modes of education [9]. E-learning is used to refer to learning environments in which electronic devices such as computers (phones inclusive) are used as educational delivery systems. These can include the use of media like email, social media apps like WhatsApp and Telegram, and World Wide Web platforms to compliment print-based materials spread within an unlimited geographical environment [10]. E-learning has been shown to have motivated students to learn and students have adjudged that they were satisfied with it. Lecturers have also posited that it could be used to improve teaching and learning [11]. E-learning has also been proved to provide flexibilities for the learners [12]. As a result of the emergence of a consumer-centered culture coupled with a drastic rise in information, E-learning has gained more prominence. 21st century students now demand a flexible structure that allows them to study, work and participate in family life at the same time. The request for this flexibility has made E-learning to be part of the alternative educational delivery methods [13].

\section{PROVERBS AND THEIR IMPORTANCE}

In order to fully appreciate proverbs and their importance, there is the need to understand the concise meaning of the term according to some credible sources.

\subsection{Proverbs}

From the work of Babasola, proverbs can be seen as a popular short saying with words of advice; verbal expression consisting of compressed statements in figurative language; a popular saying embodying some familiar truth [14]. According to Olajide, proverbs are described as familiar sayings of folk wisdom usually compressed in form and frequently involving jingles that catch attention [15]. Proverbs were generally described to be known as short folklore sentences that contain morals, wisdom and truth in a metaphorical form [16].

\subsection{Importance of Proverbs}

Osofisan and Owomoyela in their work on Yoruba proverbs, explained that proverb is the most effective strategy the Yoruba people have devised to optimize the efficacy of speech in the language [17]. The authors explained that in order to have a thorough understanding of the role that proverbs play, one must understand proper meanings of proverbs. Oripeloye and Araroba explained that Yoruba's view of the world and values are embedded into proverbs which also touch all aspects of their life in economic, social, religious and political activities [18]. Ademowo and Balogun posited that the use of proverbs and the associated lessons derived from them could help in the revival of moral and cultural values of the Yoruba people [19]. The use of Yoruba proverbs can also bring about effective communication and interaction in Yoruba plays [20]

\section{REVIEW OF RELATED WORKS}

In a bid to encourage the learning of the mother tongue by those who didn't understand the language towards addressing the extinction of the language, Oyelami developed a standalone system for learning the rudiments of Igbo language [21]. This system, unlike a web-based one, did not require Internet connectivity of which penetration in Nigeria then was poor. Sarawut explains how Moken language in Thailand was prevented from extinction through the use of information technology by a group known as Moken language documentation and preservation project (MLDPP) [22]. This group used audio and video storage media techniques in information technology for gathering information on Moken language and also storing them. The audio information was subjected to some processing to achieve effective preservation and accessing. Adéè kó , in his work on Yoruba proverbs provided a collection of up to five thousand, two hundred and thirty five $(5,235)$ Yoruba proverbs and their English translations [23]. This collection of proverbs was stored in the following website: https://muse.jhu.edu/article/221243/summary. Olajide used iconography and visualization techniques to process some selected Yoruba proverbs for the purpose of art and culture practices which was hoped to eventually resuscitate and sustain the proverbs culture in Yoruba land [24]. Oyinloye worked on how to revitalize the Yoruba proverbs through the use of intra-lingual documentation of expressions in information system storage media as a proactive measure aimed at ensuring their sustainability should they eventually die in the process of time [25]. Sawant proposed the use of translation to preserve any endangered language [26]. With translation and Internet technology, a language that perhaps has never been heard before outside of a small town can suddenly have a global audience and thus preserving it becomes easier. The author believed that among the various ways of language preservation, translation is one of the most faithful and assured tools to regenerate andre-form a particular language. Gulati in his research report, showed how to use Internet technology (storing language documentation in internet servers) to preserve an endangered language because of the wider coverage and audience [4].

\section{INFORMATION SUCCESS MODEL}

Even though, several authors have defined Information Success (IS) differently and from the perspectives of their stakes . Information Success (IS) is generally believed to be "an IS theory that seeks to provide a comprehensive understanding of IS success by identifying, describing, explaining the relationships among the most critical dimensions of success along which IS are commonly evaluated" [8]. DeLone and Mclean Success Model is the most prominent among the success models as it has been mostly used to determine the success or otherwise of information systems [27]. The model, from the time it was initially proposed in 1992, has been refined later in 1992, 2003 and 2004 from the comments received by different scholars. The model is shown below in Figure 1 to include the following success dimensions of information system [28]:

$\begin{array}{ll}\text { i. } & \text { Information Quality } \\ \text { ii. } & \text { System Quality } \\ \text { iii. } & \text { Service Quality } \\ \text { iv. } & \text { Use/Intention to use } \\ \text { v. } & \text { User Satisfaction } \\ \text { vi. } & \text { Net Benefits" }\end{array}$




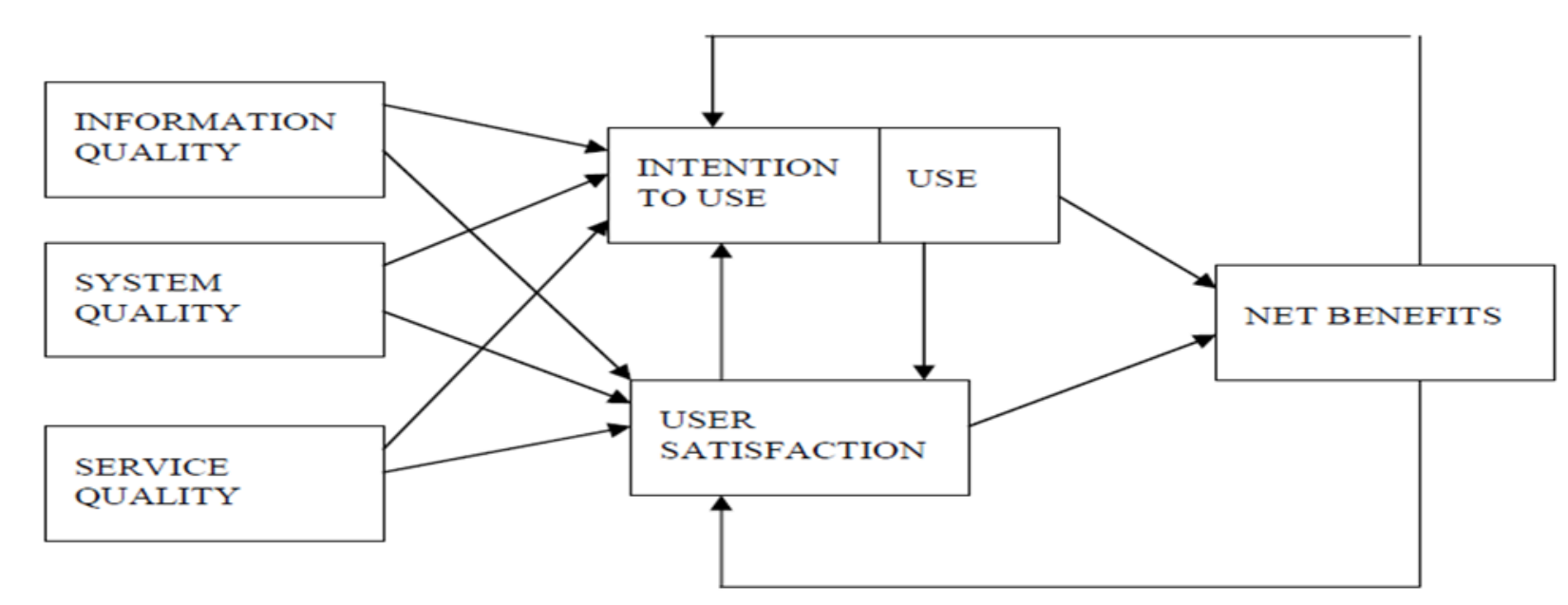

Fig 1: Success Model of DeLone \& McLean. [28](Halonen, et al., 2009)

\section{METHODS}

A comprehensive review was carried on books that contain Yoruba language proverbs, their interpretations and their usage. Elderly people who understand Yoruba proverbs and how to use them were also interviewed to document different Yoruba proverbs and when they can be used. The Androidbased Yoruba repository system was developed using JSON and Java. The proverbs were stored in a JSON file and the recorded audio files of the proverbs were imported into a folder in Android studio. The system was tested by thirty participants who read the proverbs and listened to their audio files. After each one had tested the system, they were given a questionnaire to fill to indicate their experiences. The questionnaire measured all the dimensions of Delone \& Mclean Model:

$\begin{array}{ll}\text { i. } & \text { User Satisfaction } \\ \text { ii. } & \text { Net Benefits } \\ \text { iii. } & \text { Intention to Use } \\ \text { iv. } & \text { Information Quality } \\ \text { v. } & \text { System Quality } \\ \text { vi. } & \text { Service Quality }\end{array}$

The participants were also to respond to a question on whether they supported using this system for learning Yoruba proverbs or not. Furthermore, the questionnaire also contained sections on:

\section{i. Experience with Mobile Devices/Computing}

ii. Demographic Data

The questionnaire had a scale of 1 to 5 to respectively indicate "strongly disagree", disagree", "undecided", "agree" and "strongly agree".

\section{STUDY PARTICIPANTS}

$30 \%$ rated their experience/skill in computer software usage as average, $43.3 \%$ as good and $26.7 \%$ as expert (see Figure 2). $46.7 \%$ owned laptop/notebook, $36.7 \%$ owned PDA/cell phone, $6.7 \%$ owned tablet PC while $9.9 \%$ owned other digital devices. $23.33 \%$ had owned a digital device for the past one year, $10 \%$ for the past one and a half years, $53.33 \%$ for two years and $13.33 \%$ for the past four years (see Figure 3). 3.3\% of the participants make or receive calls $1-2$ times a week,
$26.7 \%$ make or receive calls $3-4$ times weekly, $10.0 \% 5-6$ times weekly and $60.0 \%$ users make or receive calls in a week more than 7 times (see Figure 4). $66.7 \%$ of the participants are males while $33.3 \%$ are females. $43.3 \%$ of the subjects were in the age range of $15-20,46.7 \%$ in the age range of $21-30$ and $10 \%$ in the age range of 41-50 (see Figure 5). The statistics shows that the system was mostly tested by young people that mostly don't understand Yoruba proverbs and who need it most.

\section{THE ANDROID-BASED YORUBA LANGUAGE PROVERBS AND ITS SNAPSHOTS}

Once the app is launched, the user selects a proverb of his choice which displays the proverb in Yoruba, its interpretation in English and when it can be used. The user then selects the audio file of the proverb to listen to how to say it.

\subsection{Home Page}

Figure 6 below is the home page and it is the first page the user accesses after launching the system. It contains Yoruba proverbs displayed in the form of a list.

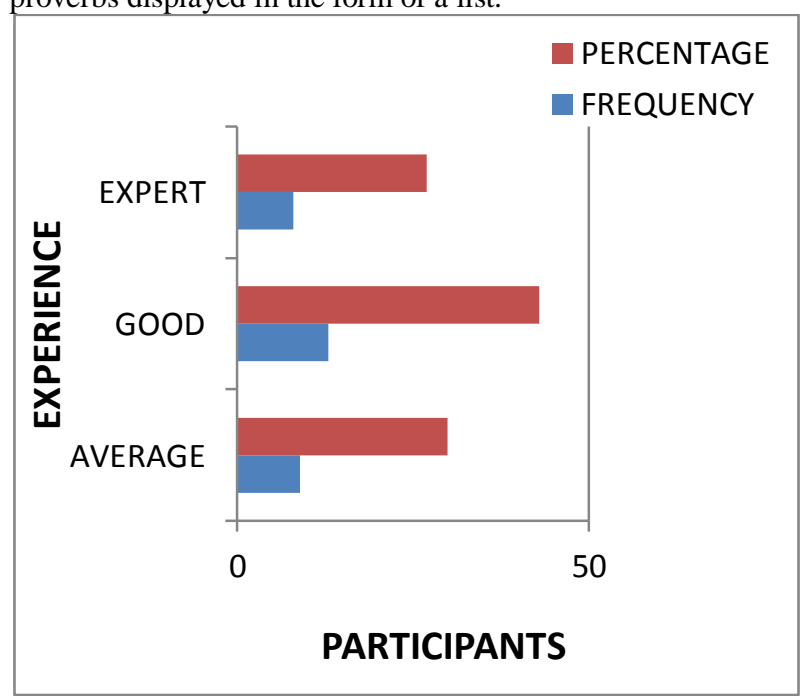

Fig 2: Experience/skill in computer software usage 


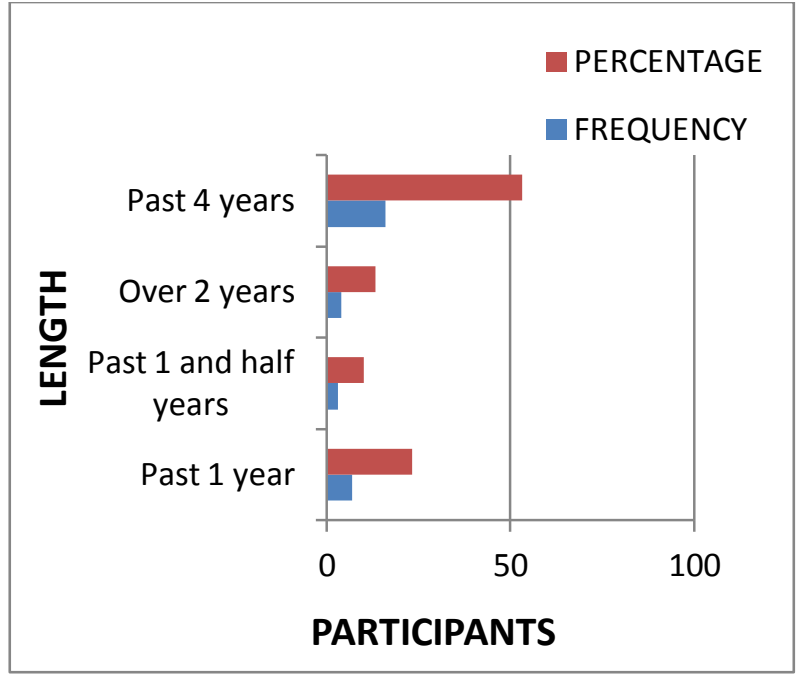

Fig 3: Length of Mobile Device Ownership

\subsection{Proverbs Details Page}

Figure 7 is the resulting page when a proverb is selected from a list of available proverbs. It displays the text information about the proverb, its use and its sound file for the learner to know how to say the proverb as a speaker icon.

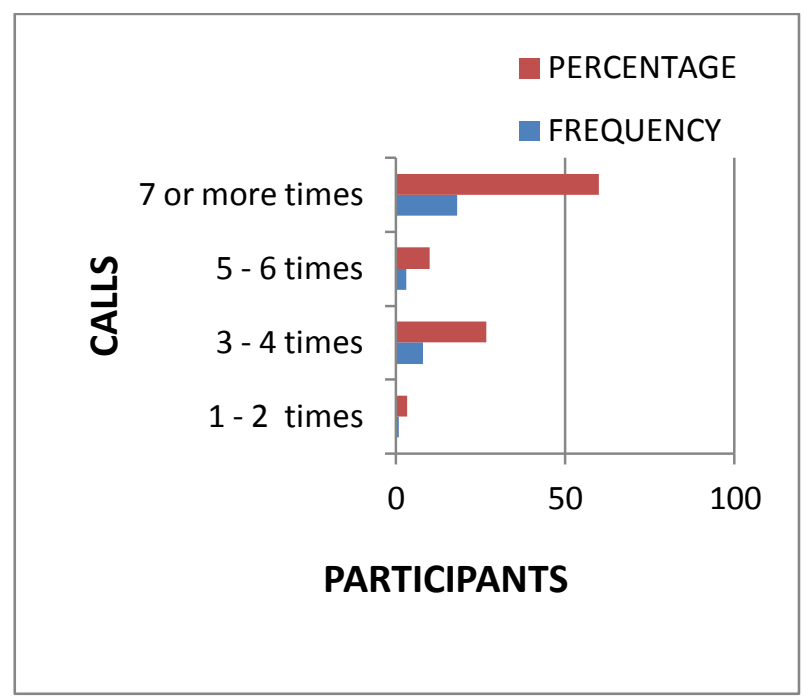

Fig 4: Weekly Calls made / receive

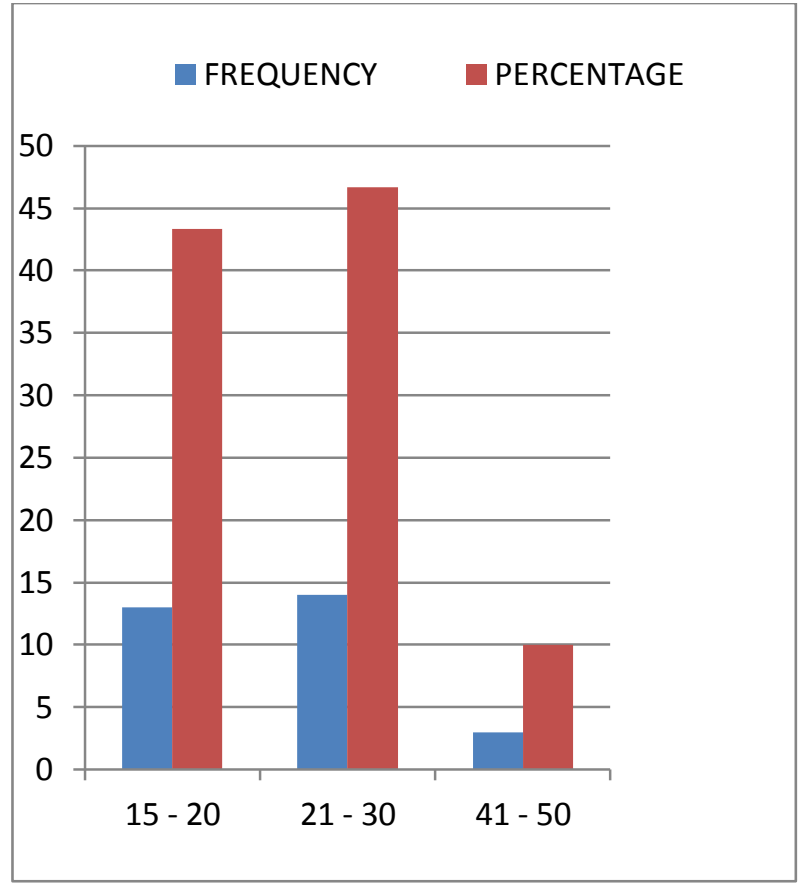

Fig 5: Age Distribution of Participants 


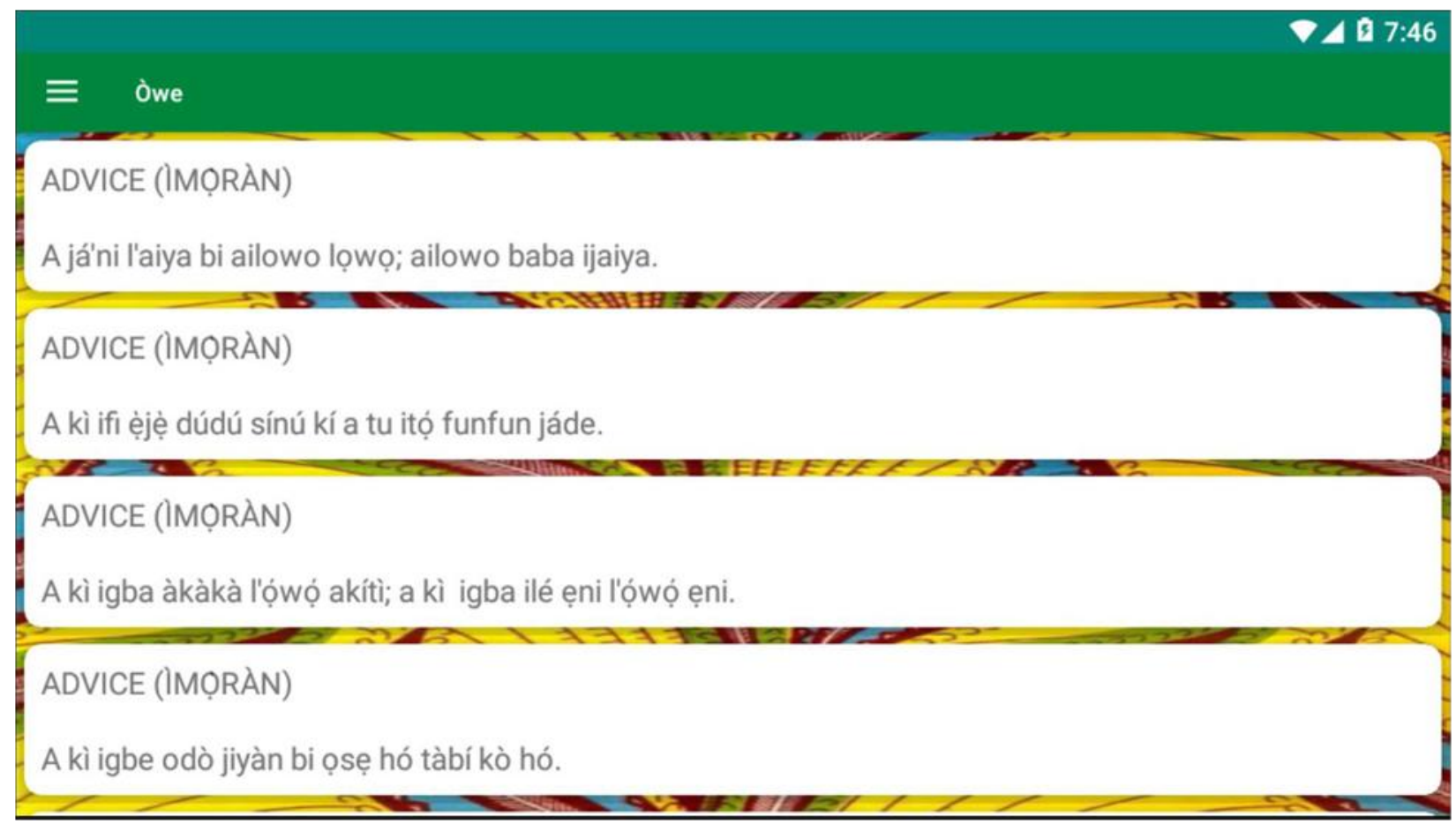

Fig 6: Home Page of the System

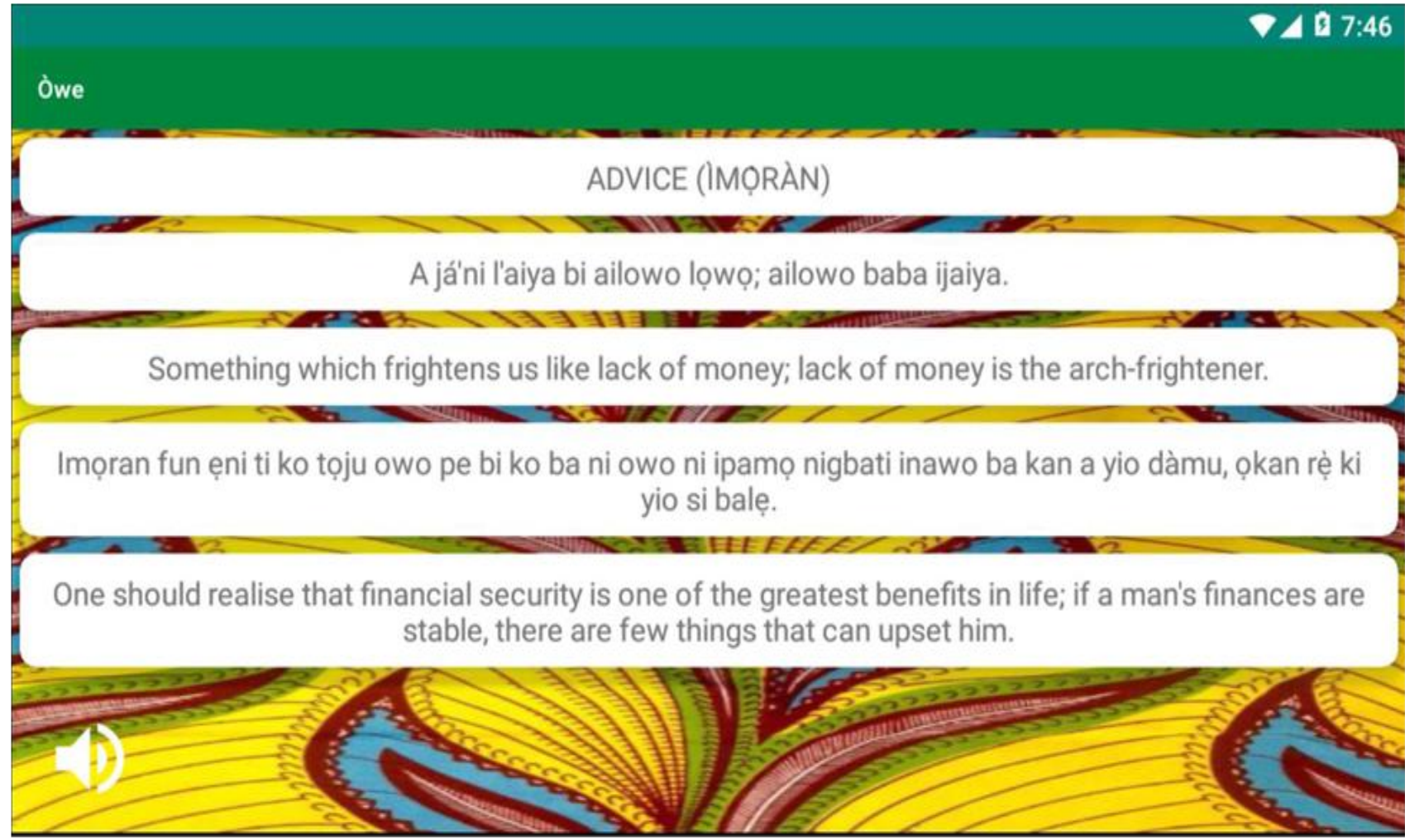

Fig. 7: Proverbs Details Page

\section{RESULTS}

$76.7 \%$ (23) of the participants responded that they supported the use of cell phone/PDA for learning Yoruba proverbs while $23.3 \%$ (7) were not in support. The reasons those who did not support the use of cell phone/PDA to learn Yoruba proverbs gave were the cost of getting the device, problem of electricity supply and lack of adequate training. For the User Satisfaction, $0(0 \%)$ strongly disagreed that they were satisfied with the system, $3(10 \%)$ disagreed that they were satisfied with the system, 7(23.3\%) were undecided, 9(30\%) agreed that they were satisfied with the system while 11 $(36.7 \%)$ strongly agreed that they were satisfied with the system. The mean rating is 3.9. For the Net Benefits of the system, the mean rating is 4.2. The mean rating for Intention to Use is 4.1. For the Acceptability of the System, 29 (96.7\%) out of the 30 participants accepted the use of the system for learning Yoruba proverbs while only 1 (3.3\%) did 
not. For Information Quality, the mean rating is 4.1, for System Quality, the mean rating is 4.4 and for Service Quality, the mean rating is 3.96 .

\section{DISCUSSION AND CONCLUSION}

A good usability study has a mean rating of 4 using a questionnaire that is scaled 1-5 and 5.6 using a questionnaire scaled 1-7 (Sauro. and Kindlund, 2005). From the results obtained, it is clear that the system was accepted as a means of learning Yoruba proverbs as the majority was in support of its usage for the purpose. The results also reveal that the users were satisfied with the system as $66 \%$ agreed that they were satisfied with the system. The mean rating of 3.9 (approximately 4) also corroborates this. The mean rating of 4.2 for the Net Benefits also means that the users benefitted immensely from using the system and the mean rating of 4.1 for Intention to Use also indicates that the participants would always want to use the system. The mean ratings of 4.1 for Information Quality, 4.4 for System Quality and 3.96 (approximately 4) for Service Quality all show the good qualities of the system. The system was also widely accepted as $96.7 \%$ accepted this innovation. The implication of all the results is that the system has been a successful one and that it could actually be exploited for learning Yoruba proverbs and their usage in a bid to arresting the extinction that looms over the language. Consequently, based on the results, the system can be exploited to arrest the extinction that looms over Yoruba language and similar ones can also be developed for the same purpose.

\section{REFERENCES}

[1] UNESCO (2008), "International Year of Languages, 2008" https://www.un.org/en/events/iyl/story1.shtml. Accessed July 18, 2020.

[2] Tatsuya Amano, Brody Sandel, Heidi Eager, Edouard Bulteau, Jens-Christian Svenning, Bo Dalsgaard, Carsten Rahbek, Richard G. Davies and William J. Sutherland (2014). Global distribution and drivers of language extinction risk. The Proceedings of Royal Society B Biological Sciences https://doi.org/10.1098/rspb.2014.1574

(2014).

[3] Neus Isern and Joaquim Fort (2014), Language extinction and linguistic fronts, Journal of Royal Society Interface (2014) http://dx.doi.org/10.1098/rsif.2014.0028

[4] Gulati Aryan (2019), Methods to preserve and prevent the extinction of endangered languages in the face of global advancements, Dubai International Academy Model United Nations 2019| 11th Annual Session http://www.diamun.org/Media/2019/Research_Reports_2 019/GA3_2.pdf

[5] Makinde, D.O. (2014), Modernisation of Creative Culture: Ona in modern Nigeria Art, Unpublished Ph.D. Thesis, Department of Fine and Applied Arts, University of Nigeria, Nssuka. http://www.iosrjournals.org/iosrjhss/papers/Vol.\%2021\%20Issue8/Version6/C2108062232.pdf DOI: 10.9790/0837-2108062232

[6] Paul Hernadi and Francis Steen (1999). The Tropical Landscapes of Proverbia: A Cross disciplinary Travelogue. University of California, Santa Barbara. Style 33. 1 (Spring 1999): 1-20.

[7] Mohammed Ayodeji Ademilokun (2014). Yoruba proverbs and the anti-corruption crusade in Nigeria.
Obafemi Awolowo University, Ile Ife, Nigeria. Inkanyiso, Jnl Hum \& Soc Sci 2014, 6(1)

[8] Alexandre, J.\& Isaías, P. (2012). September). Information systems success: measuring Wiki implementation success, based on the DeLone \& McLean model. Paper presented at Mediterranean Conference on Information Systems (pp. 212-224). Berlin: Springer

[9] Rodica Pamfilie, Bogdan Onete, Irina Maiorescu and Doru Plesea (2012). E-learning as an alternative solution for sustainable lifelong Education. Elsevier SciVerseScienceDirect, Procedia Social and Behavioral Sciences 46 ( 2012 ) 4026 - 4030. https://www.sciencedirect.com/science/article/pii/S18770 $42812019271 \quad$ DOI: $\quad 10.1016 / j . s b s p r o .2012 .06 .191$. [Accesed : July 19, 2020]

[10] Safiyeh Rajaee Harandi (2015). Effects of e-learning on students' motivation. Elsevier ScienceDirect, Procedia Social and Behavioral Sciences 181 ( 2015 ) 423 430.3rd International Conference on Leadership, Technology and Innovation Management. https://www.sciencedirect.com/science/article/pii/S18770 42815031985

[11] Marek Šolc, Jaroslav Legemza, Andrea Sütőová ,LenkaGirmanová (2012). Experiences with utilizing elearning in education process in university environment. Elsevier SciVerseScienceDirect, Procedia - Social and Behavioral Sciences 46 (2012) 5201 - 5205. https://www.sciencedirect.com/science/article/pii/S18770 42812021453/pdf?md5=7586d20a9a8d71973f9785d065 d27d75\&pid=1-s2.0-S1877042812021453main.pdfdoi:10.1016/j.sbspro.2012.06.409.

[12] Johan @ Eddy Luaran, Nazleen Samsuri, Fazyudi Ahmad Nadzri, Kamarol Baharen Mohamad Rom. (2014) .A study on the student's perspective on the effectiveness of using e-learning.Elsevier ScienceDirect, Procedia Social and Behavioral Sciences 123 ( 2014 ) $139-144$

[13] Harriman, G. (2014). Education 2.0: E-Learning Methods. ELSEVIER. Procedia-Social and behavioral Sciences. Volume 186, 13 May 2015, Pages 376-380. https://www.sciencedirect.com/science/article/pii/S187 7042815024738

[14] Osoba, Joseph Babasola (2014), The Nature, Form and Functions of Yoruba Proverbs: A Socio-Pragmatic Perspective .IOSR Journal Of Humanities And Social Science (IOSR-JHSS) Volume 19, Issue 2, Ver. IV (Feb. 2014), PP 44-56 e-ISSN: 2279-0837, p-ISSN: 2279 0845. www.iosrjournals.org

[15] Makinde David Olajide (2016), Iconography of Yoruba Indigenous Proverbs for Sustainable art Practices . IOSR Journal Of Humanities And Social Science (IOSR-JHSS) Volume 21, Issue 8, Ver.6 (Aug. 2016) PP 22-32 e-ISSN: 2279-0837, p-ISSN: 2279-0845. www.iosrjournals.org

[16] Çiler Hatipoğlu and Nilüfer Can Daşkın (2020). A proverb in need is a proverb indeed: Proverbs, textbooks and communicative language ability. South African Journal of Education, Volume 40, Number 1, February 2020. Art. \#1664, pp 937 - 951, 15 pages, https://doi.org/10.15700/saje.v40n1a1664 
[17] Femi Osofisan, OyekanOwomoyela (2006) , Yoruba Proverbs, University of LeedsCenter for African Studies (LUCAS). African Studies Bulletin 68 (2006), pp. 8385, Thursday 29 June 2006. https://lucas.leeds.ac.uk/article/yoruba-proverbs/. Accessed July 18, 2020.

[18] Henri Oripeloye and Taiwo Araroba (2018). Yorùbá Proverbs and Corruption: A Curious Convergence. Ibadan Journal of Humanistic Studies Vol. 28 No. 1 (2018) https://www.ajol.info/index.php/ibjhs/article/view/19079 3

[19] Adeyemi j , Noah Opeyemi Balogun (2014).Proverbs, values and the development question in contemporary Africa: a case study of Yoruba proverbs, Antropologija 14, sv. 2014 ). https://www.researchgate.net/publication/319310765_PR OVERBS_VALUES_AND_THE_DEVELOPMENT_Q UESTION_IN_CONTEMPORARY_AFRICA_A_CASE STUDY_OF_YORUBA_PROVERBS

[20] Ehineni Taiwo (2019). The Pragmatics of Yoruba Proverbs in Ahmed Yerima's Igatibi, Ajagunmale and Mojagbe. Issues in Intercultural Communication ISSN: 1941-7195 Volume 4, Number 1 (C) Nova Science Publishers, Inc. https://www.researchgate.net/publication/333647159_Th e_Pragmatics_of_Yoruba_Proverbs_in_Ahmed_Yerima's _Igatibi_Ajagunmale_and_Mojagbe [accessed Jul 20, 2020].

[21] Oyelami M. O. (2008), "Development of Igbo Language E-Learning System", Turkish Online Journal of Distance Education-TOJDE, 9(4):39-52.

[22] Sarawut Kraisame (2018). Language endangerment and community empowerment: Experience form community training in the Moken language documentation and preservation project .Science Direct, Kasetsart Journal of Social Sciences, 39 (2018) 244-253 2452-3151/@2017 Kasetsart University. Publishing services by Elsevier B.V https://doi.org/10.1016/j.kjss.2017.05.002

[23] Adéléke Adéèkó (2007), Yoruba Proverbs (Review). Research in African Literatures, Indiana University
PressVolume 38, Number 3, Fall 2007 pp. 202 205https://muse.jhu.edu/article/221243/pdf

[24] Makinde David Olajide (2016). Iconography of Yoruba Indigenous Proverbs for Sustainable art. IOSR Journal Of Humanities And Social Science (IOSR-JHSS) Volume 21, Issue 8, Ver.6 (Aug. 2016) PP 22-32 e-ISSN: 2279-0837, p-ISSN: 2279-0845. www.iosrjournals.org DOI: $10.9790 / 0837-2108062232$

http://www.iosrjournals.org/iosr-

jhss/papers/Vol.\%2021\%20Issue8/Version6/C2108062232.pdf

[25] Mayowa Oyinloye (2016), Instances of Gradual Vocabulary Loss in Yoruba: A Need for Documentation. Studies in Literature and LanguageVol. 13, No. 6, 2016, pp. 1-8DOI:10.3968/9103

[26] Datta G. Sawant (2013), PRESERVATION OF ENDANGERED LANGUAGES THROUGH TRANSLATION.Research Scholar,An International Refereed e-Journal of Literary Explorations.ISSN 2320 $6101 . \quad \quad$ www.researchscholar.co.in https://www.researchgate.net/profile/Dr_Datta_Sawant/p ublication/237065349_Preservation_of_Endangered_Lan guages_Through_Translation/links/00b7d51b1f5208792 b000000/Preservation-of-Endangered-LanguagesThrough-Translation.pdf

[27] Nguyen, T. D., Nguyen, T. M. and Cao, T. H., (2015). Information Systems Success : A Literature Review,pp. 242-256. Sauro, J.and Kindlund, E., 2005, April (2005). A Method to Standardize Usability Metrics into a Single Score. InCHI 2005.

[28] Halonen, R., Acton, T., Golden, W. and Conboy, K., (2009). DeLone \& McLean success model as adescriptive tool in evaluating a virtual learning environment. In Int. Conf. Organ. Learn. Knowl. Capab.(OLKC 2009), ( p. 16). 